Máthé Gábor

\title{
A KIHÁGÁS EGYSÉGES ANYAGI JOGI INTÉZMÉNY
}

\author{
Trespass as a Unitary Substantial Law Institution
}

Prof. Dr. Máthé Gábor, CSc professor emeritus Nemzeti Közszolgálati Egyetem Államtudományi és Nemzetközi Tanulmányok Kar, mathe.gabor@uni-nke.hu

A tanulmány a kriminalitás határán lévő jogellenes cselekmények 19-20. századi kodifikációjának föbb jellemzőit tekinti át, így az 1843. évi büntetőjogi javaslatok részeként a „Toldalék”-ot és az 1840:IX. (mezőrendőri) törvényt. Kiemelten elemzi a jubiláris Btk.-Kbtk.-viszonyt: az európai trichotomikus rendszert, továbbá a 20. század közepén megfogalmazott tételt, a „kihágás nem nélkülözhetetlen büntetőjogi kategória” jegyében született szabálysértést. Bemutatja a két szabálysértési törvény $(1968,1999)$ föbb jellemzőit, majd értékeli a harmadik Sztv.-t (2012). A szabályozás konklúziója, hogy a szabálysértések kvázi kihágássá „visszaválásának” folyamata: jogdogmatkai törvény.

KulcsszavaK:

dichotomikus-trichotomikus rendszer, kihágás-szabálysértés, szabálysértés „visszaalakulása” kihágássá

The study concerns the main characteristics of the $19^{\text {th }}-20^{\text {th }}$-century codification of malfeasances on the fringe of criminalism. First, it examines parts of the 1843 penal law propositions, the so-called Addendum and Act IX of 1840, the field-guard law. It pays particular attention to the jubilarian relationship of Penal Code and Trespass Code, the European trichotomic system. It analyses the thesis composed in the mid-20 century, 'the trespass is not an indispensable criminal category', and the infringement that was formulated accordingly. It introduces the two infringement laws of 1968 and 1999 and their main characteristics, then evaluates the third infrigement law of 2012. The conclusion of the regulation is that the regression of infringements into trespass is a juridical dogmatism.

KeYwords:

dichotomic-trichotomic system, trespass infringement, infringement regressing into trespass 


\section{ELMÉLETI ALAPVETÉS}

A kihágás, mint a bűncselekmények önálló csoportját jelölő fogalom, az 1791. évi francia büntető törvénykönyvvel, majd az 1810. évi Code Penal révén vonult be a büntetöjog rendszerébe. A büncselekmények súly szerinti osztályozása alapozta meg a trichotomikus (bűntett - vétség - kihágás) és a dichotomikus (büntett - kihágás) rendszerü büntetőkódexeket.

A kisebb súlyú cselekmények megítélésének egyik jelentős kérdése tehát a büncselekményekhez való viszonyuk tisztázása. Ebből következik, hogy ezek a büntetőjogi felelösségnél enyhébb felelősségi formát alapoznak meg. A további problémát az jelenti, hogy a kisebb súlyú cselekmények nem homogén természetüek. Azaz igen jelentős az a kör, amely nem egyszerüen a büncselekmények büntetőjogilag már nem értékelhető alakzataként, hanem valamilyen normaszegés következményeként jelenik meg.

E komplex jellegü jogellenes magatartások az intézményfejlődés során a büntetőjogi alapelvekkel, és a hatalommegosztási tannal történő „összebékítést” is szükségessé tették. Alkotmányjogi kérdésként vetődött fel továbbá, hogy az igazgatási szervek büntető itélkezést folytathatnak-e, kiszabhatnak-e büntetéseket - azaz megsérthetik-e az igazságszolgáltatás bíróságok útján posztulátumát.

A vonatkozó jogi szabályozás „évszázados dilemmája” - leegyszerüsítve - egy ellentétpárban fejezhető ki:

- a kihágás a büntető anyagi jog része - elbírálása bírósági és közigazgatási hatáskörben történik;

- a közigazgatás, posztulátumok szintjén a büntetőhatalom gyakorlásából ki van rekesztve.

A két egymást kizáró lehetőség közötti választás kényszerüségének eredője a közigazgatási büntetőjog. Az anyagi jogi egység és az eljárásban a cselekmények szerinti megosztottság értelemszerüen a bűncselekmények további minőségi osztályozását felvállaló elméletek térhódításához vezetett. ${ }^{1}$

A polgári kori büntetőjogi elméletek fokozatosan épültek egymásra. A bűncselekmény - kihágás első elhatárolási kísérleteiben lényegében már megjelenik a közigazgatásellenesség fogalmi köre, azaz a „törvényes rend múló jelentőségű megzavarása”, amely formális büntetöjogi és büntetőjogon kívüli szabályszegésként vagy áthágásként is értékelhetö.

A természetjogi felfogás pedig a büncselekmény az embernek a természettől fogva létező jogosítványait sérti, míg a kihágás csak a pozitív jogot. Ebből következett továbbá a morális tartalomban mutatkozó különbségtétel. Azaz a büncselekmények erkölcsellenesek, a természetnél fogva „önmagukban tilalmazott” mala in se cselekmények, míg a kihágások az ember alkotta jog folytán bűncselekménnyé lett mala prohibita cselekmények. A veszélyeztetési koncepcióval ugyanakkor a közigazgatás-ellenesség újabb elkülönítő ismérve,

Máthé Gábor (szerk.): Közigazgatási büntetőjog. Budapest, Tankönyvkiadó, 1988. 155-165. 
az absztrakt veszély jelent meg. A jogtárgy szintjén, illetve a jogellenesség alapján alapuló elméletek pedig a büntetőjog megoszthatóságát juttatták kifejezésre, amelynek eredménye az igazságügyi, illetve a közigazgatási büntetőjog lett.

A közigazgatási büntetőjog elméletét a magyar jogtudományban Angyal Pál alapozta meg. E szerint a kihágás rendbontó közigazgatás-ellenesség, amely a büntetthez hasonlóan jogellenes, a közigazgatás-ellenesség egyben a közigazgatási büntetőjogba tartozó cselekményeket jellemző materiális ismérv. A büntetőjog materiális eleme társadalomra veszélyességet hordoz, de ez a kihágásoknál olyan csekély mértékű, hogy a közigazgatásellenességben feloldható. A közigazgatás-ellenesség egyfelől a kisebb fokú társadalomra veszélyesség szinonimája, másrészt pedig a közigazgatás müködésének rendjét akadályozó veszélyeztető cselekményeknek az előbbivel azonos mértékű kifejezője.

\section{KIHÁGÁSI JOGALKOTÁS A 19. SZÁZADBAN}

Ismert, hogy a jogállamot realizáló, továbbá nagy jogalkotásokat teremtő 19. század konzekvens volt az alkotmányos, illetve a büntetőjogi alapelvek alkalmazása terén.

Az intézmény fejlődésének első szakasza a büntetőjogi kodifikáció egyetemes eredményeihez és hazai kísérletéhez kötődött. Az 1843. évi Javaslatokhoz csatolt Toldalék (A közfenyíték alá tartozó rendőrségi kihágásokról, s azoknak büntetéséről) a Btk-tervezet büntettekröl és büntetésekről szóló részének szoros tartozéka. A büntetőjog általános és különös részre bontását a Toldalék is átvette. Az általános részben foglaltak (hatály, felelősség, stádium, elkövetők, büntetési nemek) kisebb módosításokkal a kihágásokra is kiterjedtek.

A kisebb súlyú cselekmények meghatározásának nehézségeit felismerve, az akkori kodifikáció előtt is világos volt, hogy nem csupán a kriminalitás határán mozgó cselekmények és büntetőjogi relevanciájuk a teljes kör, hanem olyan magatartások is, amelyek igazgatási viszonyból fakadnak. Ám ezekre nem lehetett általános érvényű szabályokat adni, különösen nem volt mód a törvénybe foglalásukra, hanem kisebb közösségeket érintő normák alkotására is kellett törekedni.

A Toldalék felsorolta azokat a kihágás természetü szabálytalanságokat (például tüz-, vízrendészet, építésügyi, egészségügyi szabályok megszegése; utcákon, hidakon veszélyt okozó sebes nyargalás), amelyek formulázása, büntetése részben kormányszintű rendeletekben, részben törvényhatósági statútumokban történhetett. Tehát már ennél a kodifikációs kísérletnél találkozunk a mai jogi megoldás előzményével: kihágást törvény, kormányszintű rendelet és szabályrendelet határozhatott meg.

Az 1843. évi javaslatok a bűntett - kihágás egysége mellett a büntetőeljárás - rendőri eljárás párhuzamát is megteremtették. A kihágásokat elbíráló szervek nem egyesbíróságként, hanem kollegiális testületként funkcionáltak. A rendőrbíró az elöljáróság által delegált két fővel tanácsban ítélkezett. Az eljárás egészére a büntetőeljárási javaslat vonatkozó 
szakaszait kellett alkalmazni. A jogorvoslati rendszer az egyfokú fellebbezést pedig a bírói út igénybevételével kívánta megteremteni. ${ }^{2}$

A fent említett büntetőjogi javaslatok mellett az első kihágási törvényünk, a mezei rendőrségről szóló 1840: IX. tc. érdemel még figyelmet. Ez a jogszabály elsőként tett kísérletet az ügyek egy meghatározott csoportjában a veszélyeztető cselekmények összefogására és büntetésére. E cselekmények általános jellemzője volt, hogy a tevékenység vagy mulasztás kárt eredményezett. A károkozás két felelősségi formát, a kártérítési és a „rendészeti” felelősséget alapozta meg. A vétkes gondatlanságból létrejött veszélyeztető cselekmény elkövetőjét a költségtérítésen felül kétszeres kártérítés, azaz pénzbüntetés; a vétkes gondatlanság ismétlődése esetén pedig fogság sújtotta. E büntetéseknél a cselekmény jellege, súlya, illetve a felelősség mértéke volt a meghatározó. A cselekmények elbírálása a sommás eljárás alapján történt.

A kisebb súlyú, veszélyeztető cselekmények forrásainak tekintett 1840: IX. tc. és a Toldalék javaslatok olyan megoldásokat kínáltak, amelyektől - mint látni fogjuk - a későbbi kodifikáció sem tudta teljesen függetleníteni magát.

\section{A JUBILÁRIS KLASSZIKUS KIHÁGÁSI KÓDEX - A KBTK. - (1879: XL. TC.)}

A kihágási jog fejlődésének második szakaszát az 1878/79. évi kodifikáció nyitotta meg. A klasszikus büntetőjogi dogmatika remeke: a Csemegi-kódex a büncselekmények hármas felosztásának elvén alapul, a korabeli többségi külföldi büntetőjogi szabályozáshoz hasonlóan. A büntetendő cselekményeket azonban nem egy törvénykönyvben helyezte el. A büncselekményekből (bűntett - vétség) a heterogén természetű és felróhatósági szempontból már egyébként is differenciált magatartások leváltak: a kihágások külön kódexbe kerültek. A hármas felosztás összhangját a két törvénykönyv szerkezeti egysége fejezte ki. Mind a Btk., mind a Kbtk. általános és különös részre tagolódott. Az általános részt tartalmazó fejezetek a Kbtk.-ban megfogalmazott eltérésekkel lényegileg adekvátak voltak.

A Csemegi-kódex (Btk.) - Kbtk. formálisan teremtette meg az anyagi jogi egységet: a kihágás büntetőjogi intézményként jelent meg. Ám a kódex legalizálta a közigazgatási normába ütköző szabályszegés egy részének a kihágás fogalmi körébe vonását is. Igaz, hogy a közigazgatási hatóságoknak igazgatásellenes magatartások pönalizálására való jogát csak törvény által megszabott szűkebb körre korlátozva ismerte el. A közigazgatási büntetőjog látensen létezett, de csak embrionálisan, a kihágáson belül. Innen származtatható a későbbi különválás következménye; így az igazságügyi büntetőjogról, Justizstrafrecht - leválasztandó Verwaltungsstrafrecht létrehozásának kívánalma. ${ }^{3}$

Ugyancsak ismert, hogy a Kbtk. általános része két szabálycsoportot tételez. Az egyik része a statuáló jogforrásokkal, a másik része a büntetőjogi viszonyhoz való kapcsolattal

Az 1843-ik évi Magyar Büntetö-törvénykönyvi javaslat - Toldalék 1865. 136-143.

Máthé Gábor: Bagatell deliktumok? In Menyhárd Attila - Varga István (szerk.): 350 éves az Eötvös Loránd Tudományegyetem Állam-és Jogtudományi Kara. Budapest, 2018. 998-1006. 
foglalkozik. A kerettényállás csak a tárgyra, irányra nézve megjelölt hatósági rendelkezés megsértése a büntetési tétel rögzítésével. A tevékenység elemei más szabályokban öltenek testet. A másik variáns az, hogy sem a tárgy, sem a viszony nincs meghatározva, s ezekre a kormány, illetve a törvényhatóság hoz büntetőszabályt.

Így megfogalmazható az első tézisünk:

A kihágási jog egysége, a súly szerinti egységesítés mellett, a törvény és a többfokozatú büntetőrendeletek összhangjával értelmezhető csupán.

A büntetőjoggal való kapcsolatra továbbá jellemző, hogy a Btk. általános része adja az egységet, a Kbtk. pedig a különbségeket rögzíti. A Kbtk. alapvetően a gondatlan magatartásokért állapított meg felelősséget, az alanyi felróhatóságot érvényesítve.

A kihágások hatásköri elbírálását pedig a Btké. (1880: XXXVII. tc.) szabályozta. A közigazgatási büntetőhatóságok és a járásbíróságok közötti hatáskört nem arányosan osztotta meg. A túlsúlyt a közigazgatási szerveknek biztosította (80:44 az igazgatás javára). Ám a különös rész öt fejezetében rögzült cselekményeket tekintve viszont csak bírói eljárásnak volt helye, ugyanakkor a másik öt fejezet párhuzamos hatáskört tett lehetővé.

Az előzőekből következik a második tézisünk:

A Btk. - Kbtk. különös részének összevetéséböl egyértelmü, hogy a súly szerinti egységesítés és ennek megfelelö hatásköri megosztás Janus-arcú volt. Az elöbbiben a heterogenitás húzta át az egységet, az utóbbiban a következetlenség a garanciális követelményeket. Összegezve megállapitható, hogy a múlt század végi kodifikáció sem tudott úrrá lenni az ellentmondásos helyzeten. Egyben azonban következetes volt: a differenciáltságot egy általános szabályozástechnikában próbálta feloldani. ${ }^{4}$

\section{A KIHÁGÁS INTÉZMÉNYTÖRTÉNETÉNEK ZÁRÓSZAKASZA}

A 19. század jogelvekhez kötődő szabályozási gyakorlata a 20. század közepére átalakult. Közismert, hogy a jog tartalma és formája között az összefüggés ugyanis nem funkcionális, mivel a jogpolitikai célok különböző dogmatikai elképzelésekben ragadhatók meg. Így a Kbtk. általános része 1951. január 1-jéig, a Rendőri Büntető Szabályok (Rbsz.) 1952. július 15-ig maradt hatályban. A büntetőbíráskodás alakulása kétirányúvá vált. A dichotomikus (bűntett-kihágás) rendszert, a bűncselekmények súly szerinti megosztásának szűkítésével az 1950. évi II. törvény (Btá.) hívta életre. A kihágás megítélésének pedig különös vonása lett, hogy a büntettel azonos társadalomra veszélyességet hordozott. A különbségtétel csak a jogkövetkezményben jelentkezett.

$4 \quad$ Király Tibor: Kihágások a magyar jogban. In Móra Mihály (szerk.): Tanulmányok az állam-és a jog kérdései köréböl. Budapest, Jogi és Közgazdasági Könyvkiadó, 1953. 87-128. 
A Btá. hatálya ugyanakkor nem terjedt ki a kihágási jog különös részére. Ezt általános érvénnyel az 1951. évi 35. törvényerejü rendelet (Kihágási Eljárás Szabályai - KESz) határozta meg. Ebből következett, hogy a kihágás bűntett megítélésében inkább a hatáskörrel felruházott fórumoknak, s nem a törvényeknek volt meghatározó szerepe.

A kihágást elbíráló szervek különbözősége, az eljárás megkettőzése (Bünvádi perrendtartás; KESz), az eljárás funkcióinak egybeolvadása (a nyomozószerv egyben bíráskodik) elkerülhetetlenné tették a fórumrendszer egyszerűsítését. Ezt részben az 1953. évi 16. tvr. teljesítette. Megszüntette a rendőrségi kihágási bíráskodás jogkörét, az általános hatáskörön pedig a helyi tanács Végrehajtási Bizottsága és a bíróság osztozott.

Az úgynevezett jogalkotási „tradicionális korszak végét” így a büncselekmények súly szerinti felosztásának megszüntetése, az egységes bűntett fogalmon nyugvó anyagi büntetőjog megteremtése jelentette, ami az 1955. évi 17. tvr.-rel következett be. A tvr. a kihágások egy részét a büntettekhez sorolta, a jelentősebb hányadukat pedig a szabálysértés gyüjtőfogalom alá vonta. Megerősítette azt a korabeli szakirodalmi tételt, hogy a kihágás nem nélkülözhetetlen büntetőjogi kategória. Röviden formulázva, fö jellemvonása volt a fórumrendszer egységesítése, a büntetőjogtól való eltávolodás, és az államigazgatási felelősségen nyugvó konstrukció megteremtése, amely a szabadságkorlátozási szankciót is kiiktatta.

\section{A SZABÁLYSÉRTÉSI JOGI KONCEPCIÓK A KÉT SZTV.-BEN $(1968,1999)$}

Az új jogintézményt, a szabálysértést releváló törvényerejű rendeletet követően az Igazságügyminisztérium mellett életre hívott Igazságügyi Tanács kodifikációs testülete széles körű szakmai vita keretében, majd egy felkért professzori team közreműködésével vizsgálta az elméleti variánsokat, a szervezeti - eljárási kérdéseket. ${ }^{5}$ A büntetőjog-történeti szempontból meghatározó értékű levéltári források bemutatására vállalkozó, közelmúltban megjelent tanulmány hasznos „iránytü” a közel egy évtizedes szakmai tervekről. Ilyen előkészületekkel kezdte „újkori karrierjét” a szabálysértés az államigazgatás rendjét sértő, veszélyeztető magatartásokkal, amelyekhez az első Szabálysértési törvényben (Sztv.) - 1968. évi I. törvény - a társadalmi együttélési szabályok elleni magatartások is járultak, ami egyértelművé tette, hogy az új intézmény továbbra is „Janus-arcú” maradt.

Igen kifejezően értékeli mindezt a kiváló igazgatási jogász Szatmári Lajos professzor meghatározó közigazgatási dogmatikai monográfiájában: „[A]z államigazgatási szervek tevékenységével kapcsolatos jogellenes magatartásokkal nem a társadalmi együttélési szabályokat sértő magatartások állnak szemben, hanem az un. bagatell büntetőjogba tartozó szabálysértési tényállások."'

Magyar Nemzeti Levéltár - Igazságügyminisztérium - Igazságügyi Tanács Iratok; lásd: Máthé (2018) i. m. Szatmári Lajos: A bírság a magyar államigazgatásban. Kandidátusi értekezés. Budapest, ELTE Állam- és Jogtudományi Kar, 1990. 19-30. 
Ezt a tézist erősíti a téma ugyancsak kiemelkedő képviselője, Madarász Tibor professzor kiváló kismonográfiájában:

„[A] bagatell büntetőjoghoz tartozó tényállások, a »kis bűncselekmények« (a kriminális szabálysértések) kívül esnek az államigazgatási jogi szankció fogalmi körén [...] A kriminális szabálysértések a jogági minősítésben kétarcúak. A tételes jog szerint és a hivatalos jogi besorolás szerint ezek is államigazgatási jogi szankciók. Elméleti mérce alapján azonban ez az álláspont nem fogadható el, hiszen a »kis bűncselekmények« jogi szabályozása annyira büntetőjogias, hogy sokkal erősebbek a szálak, amelyek ezen cselekmények jogi rezsimjét a büntető anyagi és eljárási joghoz füzik, mint amelyek az államigazgatási joghoz kötik. Ugyanannyira, hogy a szakirodalom szinte egységesnek látszik a mai helyzet megváltoztatásának igénylésében."7

Rövid utalásként feltétlenül említendő, hogy az első Sztv.-nk, amely tagadta a büntetőjogi korrelációt, sajátos átalakuláson ment át. Az egyik trend a dekriminalizáció volt, a másik a klasszikus alanyi felelősség jelentős kibővülése a jogi személy felelősségének társításával. Ezt tetézte harmadik jellemzőként a törvényességi, pénzügyi felügyelet mellett fokozatosan kibontakozó ágazati szakmai felügyeleti tevékenység. A kettőzött felelősségre vonhatóság az alternatív választással már önmagában konfliktusteremtő tényezővé vált. Még szembetűnőbb lett a szakmai felügyeletek intézkedési jogosultságainak eltérő jellege. Meghatározott felügyeleti fajták esetében az érintett államigazgatási szerv egyben szabálysértési hatóságként is funkcionált, míg másoknál csak kezdeményezési jogkörrel rendelkezett.

A kodifikációs idősorban jelentős változást eredményezett továbbá az első kódex utáni; így az Alkotmánybíróság 63/1997. (XII. 12) határozatával született második kódex: az 1999. évi LXIX. törvény, amely kötelezően megnyitotta a bírói felülvizsgálat lehetőségét, ezzel feltámasztva a Kbtk. modell megoldását. ${ }^{8}$

\section{A HARMADIK SZTV. (2012) - A SZABÁLYSÉRTÉSEK KVÁZI KIHÁGÁSSÁ VÁLÁSA}

Az 1955-ben indult kísérlet a szabálysértés intézményének létrehozására, az átalakulások sikertelenségeivel együtt 2012-ben véget ért - írja Kis Norbert professzor a szabálysértési jog, a közigazgatási szankciók megkerülhetetlen elméleti művelője. Kifejező az értékítélete, miszerint a harmadik Sztv. „földindulást” idézett elő a közigazgatási represszió jogában. Több évtized kellett, hogy a jogpolitika levonja a következtetéseket a már az 1980-as

Madarász Tibor: Az államigazgatási jogi szankció fogalma és fajtái. Budapest, ELTE ÁJK, 1989.; lásd még: Árva Zsuzsanna: A közigazgatás quasi bíráskodási tevékenysége. Debrecen, Debreceni Egyetemi Kiadó, 2014.

8 Máthé Gábor: Csatlakozási fenntartás - Szabálysértési jogalkotási dilemma. In Lapsánszky András - Patyi András (szerk.): Ünnepi kötet Verebélyi Imre 70. születésnapjára. Rendszerváltás, demokrácia és államreform az elmúlt 25 évben. Budapest, Akadémiai Kiadó (Wolters Kluwer), 2014. 383-394. 
években megfogalmazott tételekből, azaz ebből az időből a közigazgatási jog saját rendszertani és elvi tartományába húzta vissza a közigazgatási védelmet.

Magyarul: az egységes közigazgatási védelem koncepciója elbukott, mivel egyre szélesebb körben a szabálysértési jogon kívüli igazgatási szankciók domináltak. ${ }^{9}$

A közigazgatási ágazati jogalkotás elterelte a közigazgatási védelem represszív eszközrendszerét a szabálysértési kodifikációtól, és ágazatonként különböző szankciórendszert alkotott. Ezt a folyamatot egyébként kiváló monográfiájában, dogmatikai alapossággal Nagy Marianna professzor asszony is elemzően ábrázolja. ${ }^{10} \mathrm{Az}$ elmúlt évtized vonatkozó joggyakorlatának értékelését A közigazgatás büntetőhatalmának problematikája és a jogérvényesités hatékonyságának jogállami korlátai címü habilitációs monográfiájában talán a „legmélyebbre hatóan” végzi el Kis Norbert. Így az ellentmondásos fejlődés két hatását az alábbiakban jelöli meg: hangsúlyozza egyfelől a szabálysértési jog súlytalanná válását, represszióját, és különösen az ágazati adminisztratív büntetési rendszer expanzióját kárhoztatja. Ennek több okát megjelölve - hic et nunc - csupán két elemét helyezzük előtérbe. Az egyik: a szabálysértési jog szankciórendszerét a büntetőjoghoz viszonyító kis büntetőjog elmélete nem engedte differenciálttá tenni, míg az ágazati jogalkotás ezt az elméleti dilemmákon túllépve meghaladta. A másik okot pedig a következőkben jelöli meg a szerző: „[A]z ágazati szankciók a szabálysértési jognál hatékonyabb, elrettentőbb feltétel-rendszerben érvényesülnek, ami pedig az alkotmányos elvi keretek hiányával magyarázható.”

Továbbá dogmatikai levezetésben pedig hangsúlyozza, hogy az új Sztv. bekapcsolta az alkotmányos büntetőjog kriminalizációs tesztjét. Azaz a magatartás szabálysértéssé nyilvánításának vizsgálata során alkalmazandók az alkotmányos büntetőjog követelményei. A szabálysértéssé nyilvánításhoz az AB - helyesen - a jogi tárgy materiális veszélyeztetését igényli. Valós paradigmaváltást jelent az, hogy az alkotmánybíróság történetében először a szabálysértési jogon kívüli büntetésekre is kiterjesztette a büntetőjogi legalitás elveit. ${ }^{11}$

A végkonklúzió pedig szellemes zárógondolatot ad, ugyanis a továbbiakat tekintve keretbe foglalja a kihágástól a kihágásig terjedő idősor - 140 esztendő - megszívlelendő jogtudományi tanulságát:

A szabálysértések kvázi kihágássá válásával elértük azt az alkotmányjogi relevációt, amely felismeri, hogy a közigazgatási büntetőhatalmat csak a jogpolitikai mérlegelés választja el a büntetőjogtól.

Kis Norbert: A közigazgatás büntetöhatalmának problematikája: a jogérvényesités hatékonyságának korlátai. Kézirat. 2015.

10 Nagy Marianna: A közigazgatási szankciók elmélete. Budapest, 2002.

11 Kis Norbert: Az állami jogérvényesités és a közigazgatási büntetés dilemmái. Budapest, Dialóg Campus, 2018. $34-40$. 


\section{FELHASZNÁLT IRODALOM}

1. Az 1843-ik évi Magyar Büntető-törvénykönyvi javaslat - Toldalék 1865.

2. Árva Zsuzsanna: A közigazgatás quasi bíráskodási tevékenysége. Debrecen, Debreceni Egyetemi Kiadó, 2014.

3. Király Tibor: Kihágások a magyar jogban. In Móra Mihály (szerk.): Tanulmányok az állam-és a jog kérdései köréből. Budapest, Jogi és Közgazdasági Könyvkiadó, 1953. 87-128.

4. Kis Norbert: A közigazgatás büntetőhatalmának problematikája: a jogérvényesités hatékonyságának korlátai. Kézirat. 2015.

5. Kis Norbert: Az állami jogérvényesités és a közigazgatási büntetés dilemmái. Budapest, Dialóg Campus, 2018.

6. Madarász Tibor: Az államigazgatási jogi szankció fogalma és fajtái. Budapest, ELTE Állam- és Jogtudományi Kar, 1989.

7. Máthé Gábor: Csatlakozási fenntartás - Szabálysértési jogalkotási dilemma. In Lapsánszky András - Patyi András (szerk.): Ünnepi kötet Verebélyi Imre 70. születésnapjára. Rendszerváltás, demokrácia és államreform az elmúlt 25 évben. Budapest, Akadémiai Kiadó (Wolters Kluwer), 2014. 383-394.

8. Máthé Gábor (szerk.): Közigazgatási büntetőjog. Budapest, Tankönyvkiadó, 1988.

9. Máthé Gábor: Bagatell deliktumok? In Menyhárd Attila - Varga István (szerk.): 350 éves az Eötvös Loránd Tudományegyetem Állam-és Jogtudományi Kara. Budapest, 2018. 998-1006.

10. Nagy Marianna: A közigazgatási szankciók elmélete. Budapest, 2002.

11. Szatmári Lajos: A bírság a magyar államigazgatásban. Kandidátusi értekezés. Budapest, ELTE Állam- és Jogtudományi Kar, 1990.

Jogi források

1. 1840. évi IX. törvénycikk a mezei rendörségről

2. 1950. évi II. törvény a büntetőtörvénykönyv általános részéről

3. 1879. évi XL. törvénycikk a magyar büntető törvénykönyv a kihágásokról

4. 1880. évi XXXVII. törvénycikk a magyar büntetö-törvénykönyvek (1878:V. törvénycikk és 1879:XL. törvénycikk) életbeléptetéséről

5. 1968. évi I. törvény a szabálysértésekről

6. 1951. évi 35. törvényerejü rendelet a kihágási bíróságokról és azok eljárásáról (dec. 28.)

7. 1953. évi 16. tvr. a rendőrségi kihágási bíráskodás megszüntetése és a kihágási eljárásra vonatkozó egyes rendelkezések módosítása (aug. 28.)

8. 1955. évi 17. tvr. a kihágás intézményének és a kihágási bíráskodásnak megszüntetéséről (jún. 8.) 
Prof. Dr. Máthé Gábor, CSc professor emeritus a Nemzeti Közszolgálati Egyetem Államtudományi- és Nemzetközi Tanulmányok Karán, valamint az Eötvös Loránd Tudományegyetem Állam- és Jogtudományi Karán. Fő kutatási területei a magyar alkotmány és közigazgatás jogintézményeinek története, a közigazgatás és a bíráskodás határterületeinek egyes kérdései, valamint a közigazgatás büntetőhatalma. 